\title{
Detection of baculovirus associated with white spot syndrome (WSBV) in penaeid shrimps using polymerase chain reaction
}

\author{
Chu-Fang Lo ${ }^{1, *}$, Jiann-Horng Leu ${ }^{2}$, Ching-Hui Ho ${ }^{1}$, Chau-Huei Chen ${ }^{1}$, Shao-En Peng ${ }^{1}$, \\ You-Tzung Chen ${ }^{1}$, Chih-Ming Chou ${ }^{1}$, Pei-Yan Yeh ${ }^{1}$, Chang-Jen Huang ${ }^{2}$, \\ Hsin-Yiu Chou ${ }^{3}$, Chung-Hsiung Wang ${ }^{4}$, Guang-Hsiung Kou ${ }^{1}$ \\ ${ }^{1}$ Department of Zoology, National Taiwan University, Taipei, Taiwan, ROC \\ ${ }^{2}$ Institute of Biological Chemistry, Academia Sinica, Taipei, Taiwan, ROC \\ ${ }^{3}$ Department of Aquaculture, National Taiwan Ocean University, Keelung, Taiwan, ROC \\ ${ }^{4}$ Department of Plant Pathology and Entomology, National Taiwan University, Taipei, Taiwan, ROC
}

\begin{abstract}
White spot syndrome associated baculovirus (WSBV) is the causative agent of a disease which has recently caused high shrimp mortalities and severe damage to shrimp cultures. In this study, a strain of WSBV from black tiger shrimp Penaeus monodon was used to develop a diagnostic tool for the detection of WSBV and related agent infections in shrimp. The virions were purified from $P$. monodon infected with WSBV. Viral genomic DNA was extracted from purified virions by treating the virions with proteinase $\mathrm{K}$ and cetyltrimethylammonium bromide (CTAB) followed by phenol-chloroform extraction and ethanol precipitation. A qualitative assessment was performed using polymerase chain reaction (PCR) analysis on the viral DNA and primers specific to shrimp genomic DNA in order to monitor shrimp DNA contamination in the viral genomic DNA preparations. A. WSBV genomic DNA library was constructed and, based upon the sequence of the cloned WSBV DNA fragment, we designed a WSBV-specific primer set for PCR to detect WSBV infection in penaeid shrimp. Samples which contained WSBV DNA yielded an evident amplification product showing the expected mobility of a 1447-bp DNA fragment, whereas nucleic acids extracted from tissue samples of clinically healthy shrimp showed no such DNA fragment, thereby confirming the specificity of our primers. By PCR with this primer set, it was demonstrated that the causative agents of white spot syndrome in different shrimp species are closely related. An effective diagnostic tool is thus provided for screening shrimp for WSBV infections, and may be important in preventing the further spread of this disease.
\end{abstract}

KEY WORDS: WSBV $\cdot$ White spot $\cdot$ PmNOBIII $\cdot$ Detection $\cdot$ Penaeid shrimp baculovirus $\cdot$ PCR

\section{INTRODUCTION}

White spot syndrome associated baculovirus (WSBV) is the causative agent of a disease which has recently caused high shrimp mortalities and severe damage to shrimp cultures. WSBV has been found across different penaeid shrimp species and in different East Asian countries (Inouye et al. 1994, Momoyama et al. 1994, Nakano et al. 1994, Takahashi et al. 1994, Chou et al. 1995, Wang et al. 1995). WSBV may be closely related

\footnotetext{
•E-mail: gracelow@ccms.ntu.edu.tw
}

to hypodermal and hematopoietic necrosis baculovirus (HHNBV) reported as the pathogen of the explosive epidemic disease of prawn (EEDS) in China in 1993-1994 (Cai et al. 1995) and systemic ectodermal and mesodermal baculovirus (SEMBV) of the black tiger prawn Penaeus monodon in Thailand (Wang et al. 1995, Wongteerasupaya et al. 1995). It is well documented that the principal clinical sign of the disease is the presence of white spots on the exoskeleton and epidermis ranging from barely visible to $3 \mathrm{~mm}$ in diameter. Histopathological study demonstrates that WSBV most frequently attacks the cuticular epidermis, as evidenced by the presence in these tissues of degenerated 
cells characterized by hypertrophied nuclei (Momoyama et al. 1994, Chou et al. 1995. Wang et al. 1995). On the basis of electron microscopy, it has been suggested that the causative agent is a rod-shaped, enveloped, non-occluded virus (Inouye et al. 1994, Momoyama et al. 1994, Nakano et al. 1994, Takahashi et al. 1994, Chou et al. 1995, Wang et al. 1995). Several independent experiments have demonstrated the reproducibility of the white spot syndrome in healthy shrimp by experimentally infecting them with WSBV prepared from the filtrate of spontaneously diseased shrimp homogenate by either injection or immersion (Momoyama et al. 1994, Nakano et al. 1994, Chou et al. 1995). Wang et al. (1995) successfully purified WSBV from diseased black tiger shrimp. In negatively stained preparations, the purified virions were indistinguishable in morphology from the virions in the filtrate for challenge tests (Chou et al. 1995. Wang et al. 1995). These results confirm that WSBV is the causative agent of the white spot disease occurring in penaeid shrimp. Thus, the white spot syndrome in penaeid shrimp associated with non-occluded baculovirus can be said to be a well-defined disease, and in the present study we used an isolate of WSBV from P. monodon as the starting material to develop a diagnostic tool for the detection of WSBV in shrimp.

For the development of effective diagnostic tools, a WSBV genomic library was constructed by cloning 'super pure' WSBV genomic DNA extracted from purified virions. This report documents the approaches and the results of this effort. In addition, the amplification of selected DNA sequence by polymerase chain reaction (PCR) promises to be a powerful diagnostic tool for the identification of pathogens (Erlich et al. 1988, Oste 1988). Based upon the sequences of the cloned WSBV DNA fragments, we have designed a WSBV-specific primer set for PCR. In this paper, we describe the details of the use of this primer set and PCR for the detection of WSBV infection in penaeid shrimps.

\section{MATERIALS AND METHODS}

WSBV genomic DNA library construction. Virus purification and extraction of viral DNA: The same batch of the frozen WSBV-infected black tiger shrimp Penaeus monodon as we used for our previous study (Wang et al. 1995) was the source of the virus, and the formal name of this strain of WSBV is PmNOBIII (the third non-occluded baculovirus reported for $P$. monodon) according to the criteria set forth in Francki et al. (1991). The purification of the virions was carried out as described proviously (Wang et al. 1995) The extraction of viral genomic DNA from purified virions was performed by treating the virions with proteinase $\mathrm{K}$ and N-cetyl $\mathrm{N}, \mathrm{N}, \mathrm{N}$-trimethylammonium bromide (CTAB) followed by phenol-chloroform extraction and ethanol precipitation (Wilson 1994). Briefly, the gradient-purified virions were incubated in TE buffer (10 mM Tris- $-\mathrm{HCl}_{1} 1 \mathrm{mM}$ EDTA, pH 7.6) containing $100 \mathrm{mM} \mathrm{KCl}, 1 \%$ SL.S (N-lauryl sarcosine) and $0.2 \mathrm{mg}$ $\mathrm{ml}^{-1}$ proteinase $\mathrm{K}$ at $65^{\circ} \mathrm{C}$ for $3 \mathrm{~h}$. After incubation, $5 \mathrm{M}$ $\mathrm{NaCl}$ was added to adjust the $\mathrm{NaCl}$ concentration of the DNA solution to $0.7 \mathrm{M}$. Next, $1 / 10$ vol. CTAB/ NaCl $(10 \% \mathrm{CTAB}$ in $0.7 \mathrm{M} \mathrm{NaCl})$ was added slowly and mixed thoroughly before incubation at $65^{\circ} \mathrm{C}$ for $10 \mathrm{~min}$. Following 2 extractions with an approximately equal volume of chloroform/isoamyl alcohol and 2 extractions with an equal volume of phenol/chloroform/ isoamyl alcohol, the DNA was precipitated with 2 voiumes absolute ethanol, and washed with coid $70 \%$ ethanol. The dried DNA pellet was dissolved in a suitable amount of $0.1 \times \mathrm{TE}$ buffer at $65^{\circ} \mathrm{C}$ for $30 \mathrm{~min}$, and then stored at $4^{\circ} \mathrm{C}$ until use.

Preparation of shrimp DNA for PCR as a control: The primers specific to shrimp genomic DNA for PCR were used to monitor shrimp DNA contamination in the WSBV genomic DNA preparations. For this purpose, 2 primers were designed from the highly conserved regions of 18S rRNA sequence of decapods, based on published sequences (Kim \& Abele 1990), a computerized data file (GenBank, National Institute of Health, MD, USA) and sequence alignment analysis using the program $\mathrm{PC} /$ GENE (Intelligenetics, Inc., Campbell, CA, USA). By pairing the forward primer 143F (5'-TGC CTT ATC AGC TNT CGA. TTG TAG-3', where N represents $G, A$, T or C) with a reverse primer, 145R (5'-T'TC AGN TTT GCA ACC ATA CTT CCC - $3^{\prime}$ ), the shrimp DNA is expected to yield a PCR product of 848 base pairs (bp) corresponding to nucleotide sequences 352 to 1200 of $18 \mathrm{~S}$ rRNA of the penaeid shrimp Penaeus aztecus.

The genomic DNAs extracted from the muscle of healthy Penaeus monodon or $P$. japonicus were used as positive control for PCR. The deproteinized genomic DNA of the shrimp was prepared according to the method for preparation of genomic DNA from mammalian tissue (Strauss 1994). Briefly, $200 \mathrm{mg}$ muscle tissue excised from the abdomen of the shrimp was rapidly frozen in liquid nitrogen and crushed to a fine powder. The processed tissue was placed in $2.4 \mathrm{ml}$ digestion buffer $(100 \mathrm{mM} \mathrm{NaCl}, 10 \mathrm{mM}$ Tris- $\mathrm{HCl}, \mathrm{pH} 8$, $25 \mathrm{mM}$ EDTA, pH $8,0.5 \%$ sodium dodecyl sulfate, $0.1 \mathrm{mg} \mathrm{ml}^{-1}$ proteinase $\mathrm{K}$ ) and incubated at $65^{\circ} \mathrm{C}$ for 12 to $18 \mathrm{~h}$. The digest was deproteinized by successive phenol/chloroform/isoamyl alcohol extractions, recovered by ethanol precipitation, and dried and resuspended in $0.1 \times \mathrm{TE}$ buffer at $65^{\circ} \mathrm{C}$ for $30 \mathrm{~min}$, and then stored at $4^{\circ} \mathrm{C}$ until use for PCR.

WSBV genomic DNA library construction: The WSBV genomic DNA without shrimp DNA contamina- 
tion was digested with Sall restriction endonuclease (BRL Life Technologies Inc., Gaithersburg, MD, USA) at $37^{\circ} \mathrm{C}$ for $3 \mathrm{~h}$ in order to obtain DNA fragments, and the fragments were then ligated into Sall cleaved pUC 19 plasmid vector in the presence of T4 DNA ligase at $16^{\circ} \mathrm{C}$ overnight. The competent Escherichia coli DH $5 \alpha$ cells were transformed with the resulting plasmids and plated on ampicillin/isopropyl- $\beta$-D-thiogalactopyranoside (IPT(i)/5-bromo-4-chloro-3-indolyl- $\beta$-Dgalactopyranoside (X-gal) agar plates. After using the miniprep method to screen the white ampicillin-resistant transformants for the presence of the appropriate recombinant plasmids, both strands of the plasmid inserts were sequenced with double-stranded DNA templates using a Sequenase kit (United States Biochemical Corp., Cleveland, OH, USA) with M13/pUC Sequencing Primers (BRL Life Technologies Inc.), and subsequently, specific internal primers.

Amplification of WSBV DNA fragment from DNA extracted from purified WSBV virions. Oligonucleotide primers (146F and 146R) were used for the amplification of WSBV DNA fragments. Primers $146 \mathrm{~F}$ and $146 \mathrm{R}$ were designed on the basis of the DNA sequence of a cloned WSBV 1461-bp Sall DNA fragment in recombinant plasmid (pms146). The following are the sequences of the primers: 146F1, 5'-ACT ACT AAC TTC AGC CTA TCT AG-3'; 146R1, 5'-TAA TGC GGG TGT AAT GTT CTT ACG A-3' With this primer set, a 1447-bp fragment is expected to be amplified from WSBV genomic DNA. The internal primers (146F2, 5'GTA ACT GCC CCT TCC ATC TCC A-3'; and 146R2, 5'-TAC GGC AGC TGC TGC ACC TTG T-3') were used to confirm that the amplified fragment was indeed from the WSBV 941 -bp SalI DNA fragment.

The deproteinized DNA samples extracted from purified WSBV virions and from the muscle of the healthy shrimp were used as DNA templates for the evaluation of the specificity of the primers by PCR

Amplification of WSBV DNA fragment from DNA extracted from tissues of infected shrimp. The diseased shrimp consisted of shrimp naturally and experimentally infected with WSBV. For experimental infection, the healthy shrimp (average body weight: $0.5 \mathrm{~g}$ ) were infected with. WSBV using the method described in Chou et al. (1995). Five days after infection, the DNA was extracted from 3 experimentally infected shrimp and 3 healthy shrimp and checked by PCR with the use of WSBV-specific primers (146F1 and 146R1) and shrimp DNA-specific primers (143F and 145R).

PCR amplification and analysis of products. The deproteinized DNA samples used for amplification totaled 0.1 to $0.3 \mu \mathrm{g}$ in a $100 \mu \mathrm{l}$ reaction mixture containing $10 \mathrm{mM}$ Tris- $\mathrm{HCl}_{1} \mathrm{pH} 9$ at $25^{\circ} \mathrm{C}, 50 \mathrm{mM} \mathrm{KCl}, 1.5 \mathrm{mM}$ $\mathrm{MgCl}_{2}, 0.1 \%$ Triton X-100, $200 \mu \mathrm{M}$ each of dNTP, 100 pmol each of primer, 2.5 units of Taq DNA Poly- merase (Promega, Madison, WI, USA). The amplification was performed in a AG-9600 Thermal Station (Biotronics Corp., Lowell, MA, USA) for 1 cycle of $94^{\circ} \mathrm{C}$ for $4 \mathrm{~min}$, $55^{\circ} \mathrm{C}$ for 1 min, $72^{\circ} \mathrm{C}$ for $3 \mathrm{~min}$; and then 39 cycles of $94^{\circ} \mathrm{C}$ for $1 \mathrm{~min}, 55^{\circ} \mathrm{C}$ for $1 \mathrm{~min}, 72^{\circ} \mathrm{C}$ for $3 \mathrm{~min}$; plus a final 5 min extension at $72^{\circ} \mathrm{C}$ after the 40 cycles. Control reactions containing no template DNA were run for all $\mathrm{PCR}$ reactions. In some PCR reactions, controls also consisted of reaction mixtures with DNA extracts from healthy shrimp. The PCR products were analyzed in $1 \%$ agarose gels containing ethidium bromide at a concentration of $0.5 \mu \mathrm{g} \mathrm{ml}^{-1}$, and visualized under ultraviolet transillumination.

Dot hybridization of DNA extracted from WSBVinfected or healthy Penaeus monodon with a DIGlabeled 1447-bp PCR product. The DNA extracted from WSBV-infected or healthy Penaeus monodon were spotted onto Hybond-N paper (Amersham, Little Chalfont, Buckinghamshire, UK) using a 96-well dot-blot vacuum filtration manifold apparatus (Schleicher and Schuell, Inc., Keene, NH, USA). The blots were airdried and denatured in $1.5 \mathrm{M} \mathrm{NaCl}, 0.5 \mathrm{~N} \mathrm{NaOH}$ for 10 min, and then neutralized in $1.5 \mathrm{M} \mathrm{NaCl}, 1 \mathrm{M}$ Tris, $\mathrm{pH}$ 7.4 for $10 \mathrm{~min}$. The blots were used for hybridization with a digoxigenin (DIG)-labeled 1447-bp PCR product following the standard molecular cloning techniques (Sambrook et al. 1989). The dot blot was hybridized at $37^{\circ} \mathrm{C}$ for $16 \mathrm{~h}$ with the DIG-labeled probe, after prehybridization at $37^{\circ} \mathrm{C}$ for $12 \mathrm{~h}$ in $50 \%$ formamide, $5 \times \mathrm{SSC}$ (0.75 M NaCl, $75 \mathrm{mM}$ sodium citrate), $1 \mathrm{mM}$ EDTA. $50 \mathrm{mM}$ Tris ( $\mathrm{pH} 8$ ), $5 \times$ Denhardt's reagent $[0.1 \%$ Ficoll$400,0.1 \%$ polyvinyl pyrrolidone, $0.1 \%$ bovine serum albumin (BSA)]. The 1447 -bp PCR product was used as a template to prepare probe using the random primer method (Boehringer Mannheim, Germany). After hybridization, the detection of the DIG-labeled nucleotides in blots was accomplished with a chemiluminescent reaction by using the DIG Luminescent Detection Kit (Boehringer Mannheim). The blot was exposed to Kodak XAR-5 film at $37^{\circ} \mathrm{C}$ for 15 to 30 min to record the chemiluminescent signal.

Southern hybridization of WSBV DNA from diseased Penaeus monodon or $P$. japonicus with DIG-labeled 1447-bp PCR product. Southern blot hybridization was performed to localize the 1447-bp PCR product within the genomic DNA of WSBV purified from the diseased Penaeus monodon or $P$. japonicus with white spot syndrome. For this purpose, $200 \mathrm{ng}$ genomic DNA of WSBV isolated from the diseased shrimp was digested with SalI, and then electrophoretically separated in $0.8 \%$ agarose gel. After acid $(0.25 \mathrm{~N} \mathrm{HCl})$ depurination and alkali $(1.5 \mathrm{M} \mathrm{NaCl}, 0.5 \mathrm{~N} \mathrm{NaOH})$ denaturation of the DNA, the gel was neutralized with $1 \mathrm{M}$ Tris ( $\mathrm{pH} 7.4$ ) and $1.5 \mathrm{M}$ $\mathrm{NaCl}$, and subsequently transferred to a Hybond-N nylon membrane using a vacuum transfer unit (Hoefer 


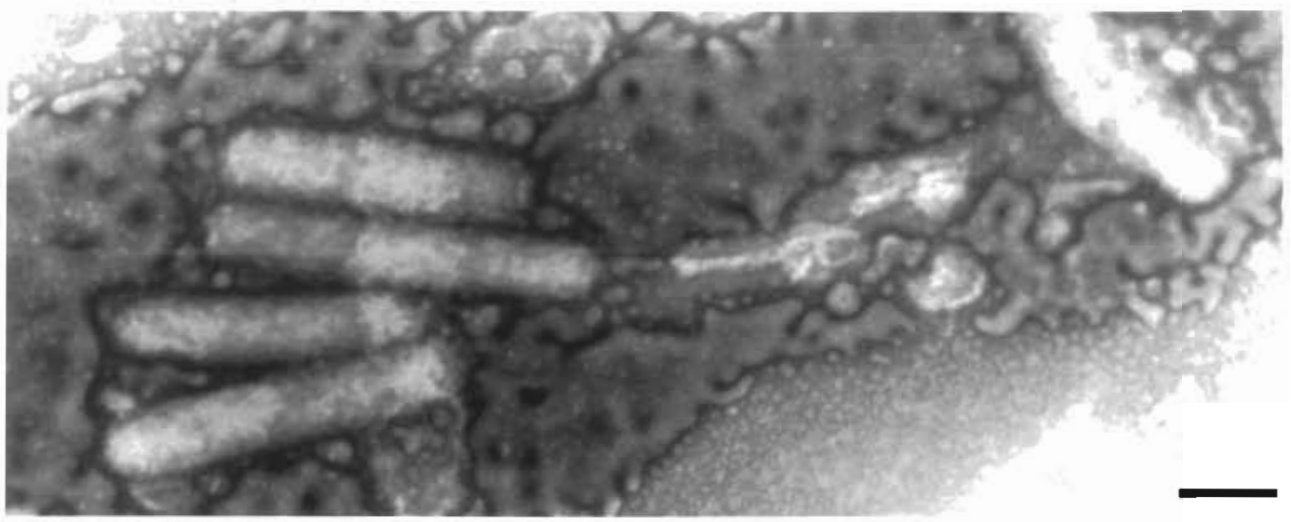

Fig. 1. Electron microscopic appearance of negatively stained WSBV virions purified by sucrose gradient centrifugation. Scale bar: $0.1 \mu \mathrm{m}$

TE 80) for $60 \mathrm{~min}$. 20× SSC was used as transfer buffer (Sambrook et ai. 1989). The biot was used for hybrudıation with a DIG-labeled 1447-bp PCR product.

\section{RESULTS}

\section{WSBV genomic DNA library construction}

Virus purification and extraction of viral DNA

Typical rod-shaped virions of WSBV were readily observed after concentration and purification by sucrose gradient centrifugation (Fig. 1). These virions were used to extract the viral DNA.

The amplification of shrimp DNA using PCR and primers specific to $18 \mathrm{~S}$ IRNA reliably resulted in the predicted 848-bp DNA fragment (Fig. 2). This provided a simple and highly sensitive method for detecting small amounts of shrimp DNA and was subsequently used to monitor shrimp DNA contamination in WSBV genomic DNA preparations for library construction. The PCR analysis shown in Fig. 3 indicates that host DNA contamination was detected in most WSBV genomic DNA preparations. However, a few samples of WSBV genomic DNA extracted from purified virion preparations were virtually free of contaminating host DNA. An example is shown in Fig. 3, lane 3.

\section{Genomic DNA library construction}

The SalI digested WSBV DNA was checked by electrophoresing a $5 \mu \mathrm{l}$ aliquot in a $0.8 \%$ agarose gel containing ethidium bromide. The WSBV genomic DNA was completely digested with Sall restriction endonuclease (Fig, 4). The size of the fragments was found to be from $15 \mathrm{kbp}$ to less than $1 \mathrm{kbp}$. From the same batch of digested TINA, a $20 \mu$ aliquot was used for library construction. Recombinant plasmids isolated from transformants were screened by SalI digestion.
The size of the inserts varied from $15 \mathrm{kbp}$ to less than $500 \mathrm{bp}$. This library provides an abundant supply of WSBV DNA enabling further study of the molecular biology of the virus.

\section{Amplification of WSBV DNA fragment from deproteinized DNA extracted from purified virions}

On the basis of the obtained DNA sequences (data not shown) of WSBV SalI DNA fragments, several primer sets were designed and evaluated by PCR for

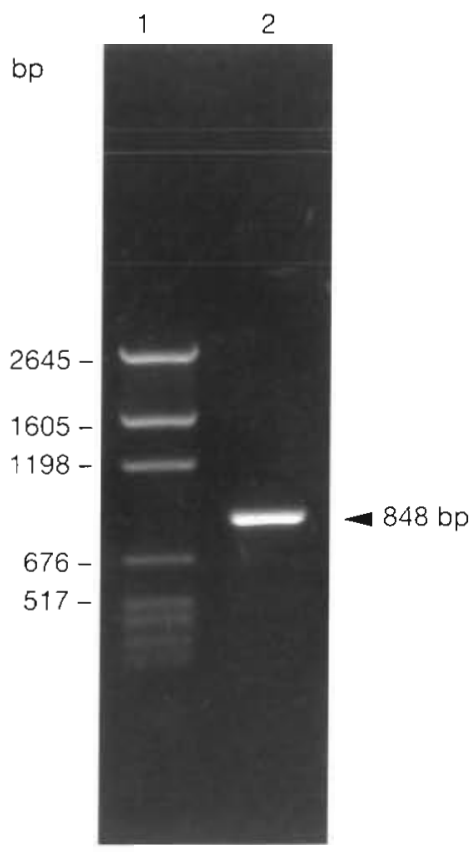

Fig. 2. Ethıdium bromide-stained agarose gel of PCR-amplified 18S rDNA fragment from shrimp genomic DNA. Two primers for highly conserved regions of the 18S rRNA sequence of decapods, $143 \mathrm{~F}$ and $145 \mathrm{R}$, were used for the reaction and primed the amplification of the 848-bp fragment from the DNA template prepared from healthy Penaeus monodon (lane 2). Lane 1. pGEN DNA size marker. Size of DNA markers indicated in base pairs (bp) 


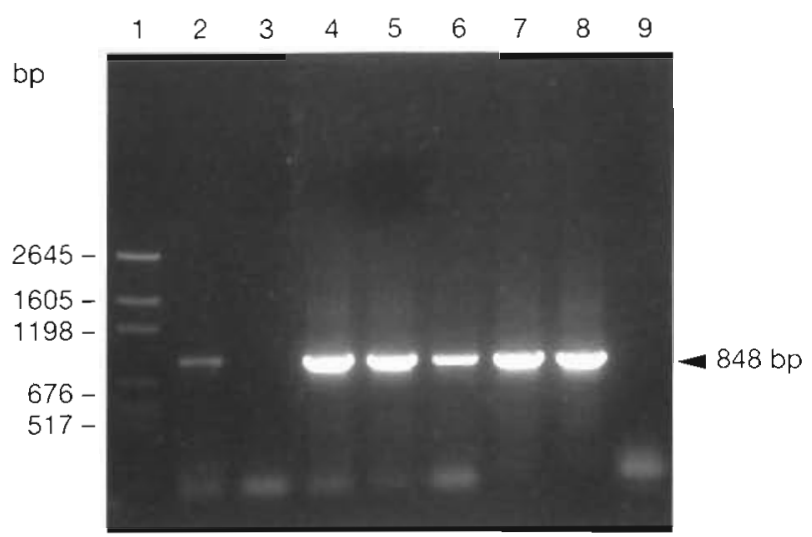

Fig. 3. Qualitative assessment using PCR and shrimp DNA specific primer set $143 \mathrm{~F}$ and $145 \mathrm{R}$ for monitoring shrimp DNA contamination in the WSBV genomic DNA preparations. The PCR products were analyzed on a $1 \%$ agarose gel. The shrimp DNA contamination is evidenced by the presence of a 848 bp PC P. product. Lane 1, pGEN DNA size marker; lanes 2-6: WSBV genomic DNA preparations as DNA template; lanes 7-8: shrimp genomic DNA prepared from healthy Penaeus monodon (lane 7 ) and $P$ japonicus (lane 8 ) as DNA template; lane 9: without DNA template. Size of DNA markers given in base pairs (bp)

their ability to identify WSBV in infected tissues Among them, the primer set 146F1-146R1 gave a consistent and an efficient amplification of WSBV DNA but not of shrimp DNA. This primer set was then chosen for subsequent parts of this study. Fig. 5 shows a diagram of the Sall 1461-bp DNA fragment cloned in plasmid pms146. The location of the amplicons and the primers used for PCR is indicated

Fig 6 shows the results of amplification using purified WSBV genomic DNA as the PCR template and primer sets specific to either WSBV DNA or to shrimp DNA. The reactions analyzed in Fig, 6, lanes 2, 5 and

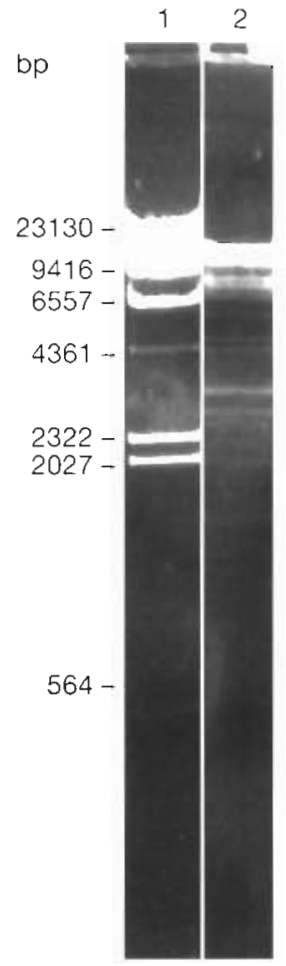

Fig. 4. Sall digested WSBV DNA fragments. WSBV genomic DN \& was digested with SalI restriction endonuclease at $37^{\circ} \mathrm{C}$ for 3 h. A $5 \mu$ l aliquot was analyzed on a $0.8 \%$ agarose gel containing ethıdium bromide showing the fragments with a size from $15 \mathrm{kbp}$ to less than $1 \mathrm{kbp}$ (lane 2). From the same batch of digested DNA, a $20 \mu \mathrm{l}$ aliquot was used for WSBV DNA library construction. Lane 1: lambda phage DNA Hind III fragment marker. Size of DNA markers indicated in base pairs (bp)

8 represent amplification using WSBV DNA primer set 146F1-146R1 and 3 independent WSBV DNA preparations, and the results demonstrate the presence of a relatively large amount of WSBV genomic DNA in the 3 tested samples, as evidenced by an intense 1447 -bp PCR product in these lanes. At least 1 of the WSBV DNA preparations is free from shrimp DNA contamination, as evidenced by the absence of a detectable PCR product of shrimp DNA in Fig. 6, lane 6. The WSBV primer set 146F1-146R1 and shrimp DNA primer set $143 \mathrm{~F}-145 \mathrm{R}$ were used simultaneously in a reaction mixture to demonstrate
Fig. 5. Diagram of the SalI-1461 bp DNA fragment cloned in plasmid pms146. Location of the primers used for PCR and amplicons is indicated. The $146 \mathrm{~F} 1$ and 146R1 prime the amplification of a 1447-bp fragment, while $146 \mathrm{~F} 2$ and 146R2 prime the amplification of $941-b p$ frag. ment. Position of 2 EcoRI sites in Sall 1461-bp DNA fragment is also indicated

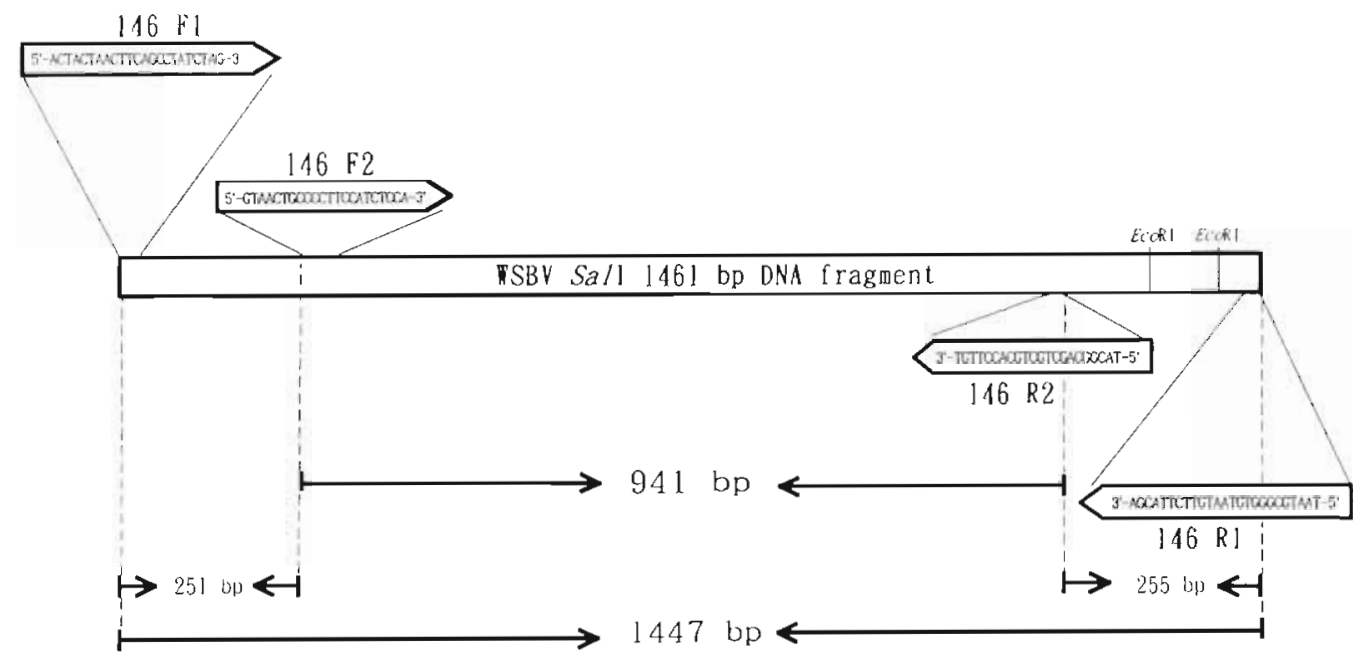




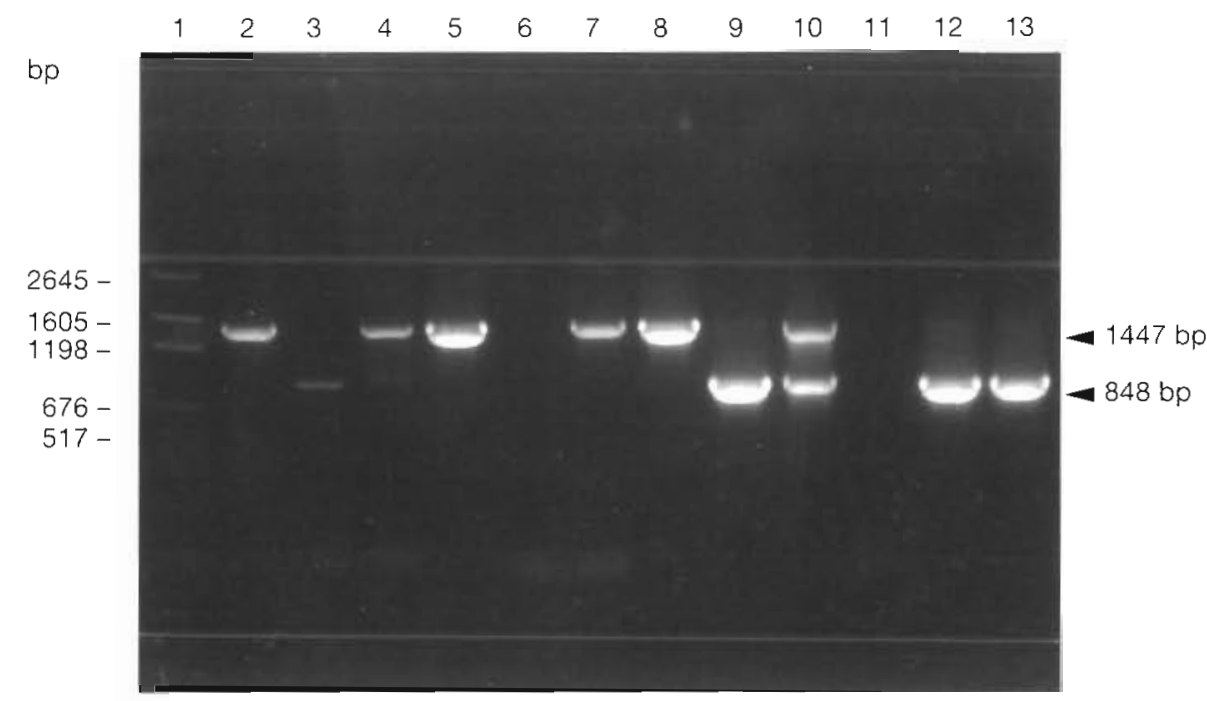

Fig. 6. PCR amplification of WSBV-specific and shrimp DNA-specific fragments using DNA templates prepared from WSBV virions purified by sucrose gradient centrifugation. The WSBV-specific primers $146 \mathrm{~F} 1$ and $146 \mathrm{R} 1$ which yield a $1447-\mathrm{bp}$ PCR product were used for reactions in lanes $2,5,8$, and 11 . The shrimp DNA-specific primers $143 \mathrm{~F}$ and $145 \mathrm{R}$ which yield an 848-bp PCR product were used for reactions in lanes $3,6,9$, and 12. In lanes 4, 7, 10, and 13, all primers (143F, 145R, 146F1 and 146R1) were added together in each of the reactions. The PCR products were analyzed on a $1 \%$ agarose gel. Lane 1 . pGEN DNA size marker; lanes 2-4: PCR products using DNA template extracted from virions purified from diseased Shrimp 1 epidermis showing shrimp DNA and WSBV DNA band; lanes 5-7: PCR product using DNA template extracted from virions purified from diseased Shrimp 2 epidermis showing only WSBV DNA band; lanes 8-10: PCR product using DNA template extracted from virions purified from diseased Shrimp 2 muscle showing intense shrimp DNA and WSBV DNA band; lanes 11-13: PCR product using DNA template extracted from healthy shrimp showing only shrimp DNA band. Size of DNA markers indicated in base pairs (bp)

approximately the proportion of WSBV DNA in template DNA. The data presented in Fig. 6 demonstrate that the WSBV-specific DNA fragment was detected as a major band in 3 independent WSBV preparations (lanes 4,7 and 10) while the shrimp DNA was detected in 2 of 3 WSBV DNA preparations (lanes 3 and 10 ). Thus template DNA contained varying proportions of shrimp DNA and WSBV DNA. It is also clear that, in spite of contamination with shrimp DNA, a large proportion of the DNA extracted from WSBV virions purified by sucrose gradient centrifugation is WSBV DNA. Meanwhile, reaction mixtures with total nucleic acid extracted from tissues from clinically healthy shrimp and WSBV DNA specific primer set 146F1-146R1 were consistently negative (Fig. 6, lane 11), thus demonstrating the specificity of this primer set.

\section{Amplification of WSBV DNA fragment from DNA extracted from the tissues of infected shrimp}

Fig 7 shows the amplification results using plasmid pms146 DNA and the DNA extracted from the tissues of Penaeus monodon and $P$. japonicus natually infected with WSBV as DNA templates. The DNA templates were amplified using either the
WSBV-specific primer set 146F1-146R1 or shrimp DNA-specific primer set $143 \mathrm{~F}-145 \mathrm{R}$. The 1447 -bp PCR product, co-migrating with DNA amplified from pure co-migrating plasmid pms146 DNA, demonstrates the presence of WSBV DNA in the total nucleic acid extracted from all the naturally infected shrimp. Examples are shown in Fig. 7, lanes 2, 5 and 8. Using the internal primer set 146F2-146R2, $10 \mu \mathrm{l}$ of these products were reamplified to yield a PCR product with the expected size of $941 \mathrm{bp}$ (Fig. 6, lanes 3,6 and 9). The results confirm the identity between amplification product and template. Shrimp DNA was amplified very efficiently using shrimp DNAspecific primer set $143 \mathrm{~F}-145 \mathrm{R}$ as shown in Fig. 7 . lanes 7 and 10. The results presented in Fig. 7, lanes 5 to 10 demonstrate that WSBV DNA could be detected with the use of WSBV IJNA-specific primer sets 146F1-146R1 and 146F2-146R2 in the presence of a large excess of shrimp genomic DNA.

Fig 8 shows the amplication result using DNA extracted from tissues of Penaeus monodon experimentally infected with WSBV as DNA templates for PCR using the primer set 146F1-146R1 Amplication of the expected 1447-bp fragment is evident for all the experimentally infected shrimp. No amplification product at $1447 \mathrm{bp}$ was present for healthy shrimp from the control group. 


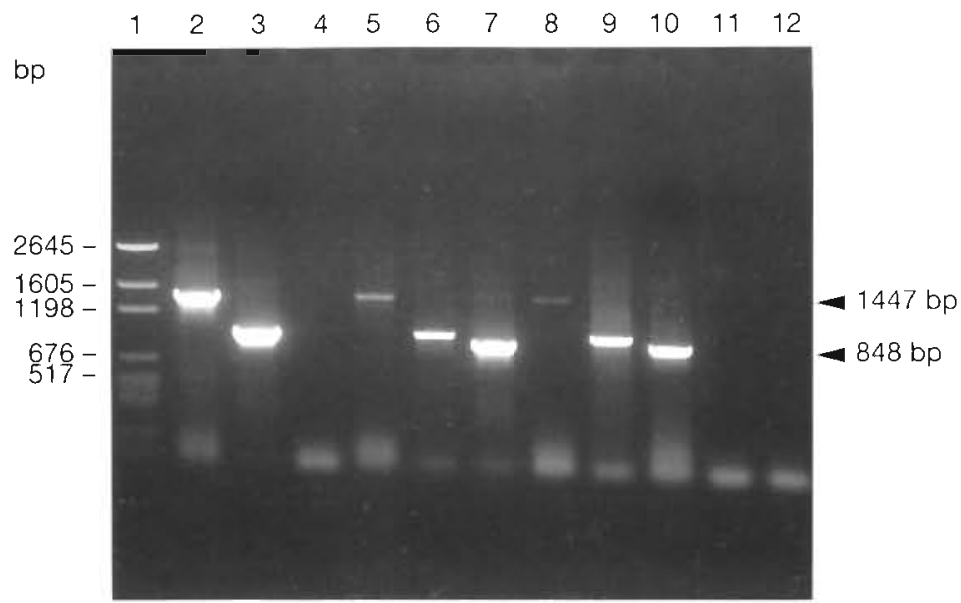

Fig. 7. PCR amplification of WSBV-and shrimp DNA-specific fragments using plasmid pms146 and DNA extracts from Penaeus monodon naturally infected with WSBV as PCR DNA templates. The WSBV-specific primers $146 \mathrm{~F} 1$ and $146 \mathrm{R} 1$ were used for reactions in lanes 2, 5, 8 and 11 . The PCR product is a 1447 bp fragment. Internal primers specific to the 1447-bp fragment, 146 F2 and 146 R2, were used for the reactions in lanes $3,6,9$, and 12; they prime the amplification of a 941-bp fragment. The shrimp DNA-specific primers $143 \mathrm{~F}$ and $145 \mathrm{R}$ were used for the reactions in lanes 4,7 , and 10 . They prime the amplification of a 848-bp fragment. The amplification products were analyzed on a $1 \%$ agarose gel. Lane 1: pGEN DNA size marker; lanes 2-4: plasmid pms146; lanes 5-7. DNA extracts from naturally infected $P$. monodon; lanes 8-10: DNA extracts from naturally infected $P$. japonıcus $s_{i}$ lanes 11 and 12 : template-free control reactions. Size of the DNA markers given in base pairs (bp)

\section{DISCUSSION}

In addition to WSBV, a variety of baculoviruses has been reported to infect decapod crustaceans since the first report by Couch $(1974 \mathrm{a}, \mathrm{b})$ and som of them cause mass mortality of the diseased animals (Lightner \& Redman 1981, Sano et al. 1981, Lester et al 1987, Johnson 1988, Johnson \& Lightner 1988, Bruce et al. 1991, Chang et al. 1992. 1993, Mari et al. 1993, Wongteerasupaya et at. 1995). These viruses are morphologically similar, and most researchers agree that the structure of the viral genome should become the much needed reference for determining the taxonomic position of crustacean baculoviruses. The development of rapid and reliable diagnostic tools using molecular approaches will be useful not only for the identification and comparative studies of the viruses but also for the screening of carriers in shrimp larvae and parental spawners. In view of these points we have focused our research on the WSBV genomic structure and on the development of rapid and sensitive diagnostic tools.

In this paper, we used shrimp DNAspecific primers in several assessments. The aims of the use of a shrimp DNA-specific

Dot hybridization of DNA extracted from WSBV-infected or healthy Penaeus monodon with a DIG-labeled 1447-bp PCR product

The results of dot hybridization demonstrate that the PCR product hybridized with DNA extracted from WSBV-infected shrimp, but did not hybridize with DNA extracted from healthy shrimp (Fig. 9) The results demonstrate the specificity of the 1447-bp PCR product.

\section{Southern hybridization of WSBV DNA from the diseased Penaeus monodon or $P$. japonicus with a DIG-labeled 1447-bp PCR product}

In order to localize the 1447-bp PCR product within the WSBV genomic DNA, Southern hybridization of WSBV genomic DNA Sall fragments was performed using a DIG-labeled 1447-bp PCR product as a probe. The results demonstrate that the 1447 -bp PCR product hybridized specifically with a WSBV genomic DNA Sall fragment of 1461 bp (Fig. 10). Both 1461-bp SalI fragments of WSBV genomic DNA prepared respectively from Penaeus monodon and $P$. japonicus were found to be positive with the probe. primer set in the present study were: (1) to assess the purity of WSBV genomic DNA preparations; (2) to evaluate nucleic acid extraction procedures for

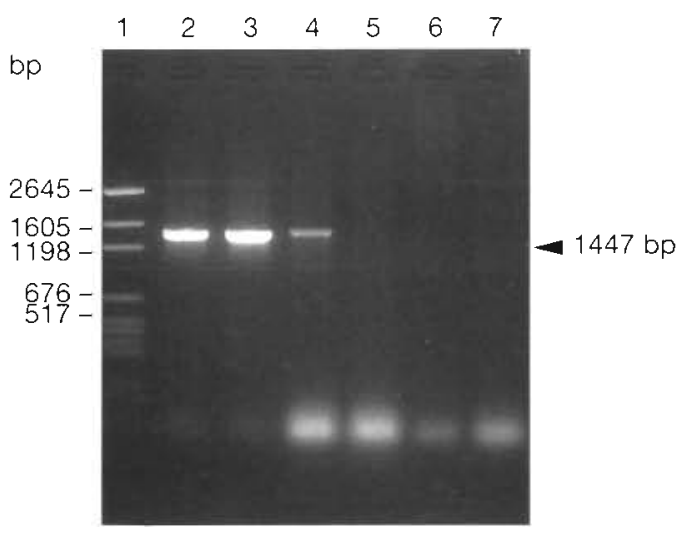

Fig. 8. PCR amplification of WSBV-and shrimp DNA-specific fragments using DNA templates prepared from Penaeus monodon experimentally infected with WSBV. The primers 146F1 and 146 R1 which yield a 1447 -bp PCR product were used for the reaction. PCR products were analyzed on a $1 \%$ agarose gel. Lane 1: pGEN DNA size marker; lanes 2-4: DNA extracts from 3 experimentally infected $P$. monodon; lanes 5-7: DNA extracts from healthy $P$. monodon of control group. Size of DNA markers indicated in base pairs (bp) 


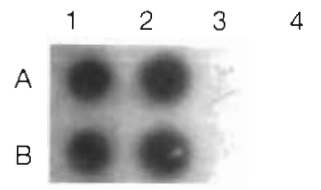

Fig. 9 Dot hybridization of DNA extracted from WSBVinfected or healthy Penaeus monodon with a DIG-labeled 1447-bp PCR product. The DNA from 2 WSBV-infected shrimp ( 1 and 2 ) and 2 healthy shrimp ( 3 and 4 ) were blotted in duplicate ( $A$ and $B$ ) onto the Hybond $-N$ paper and probed with the DIG-labeled 1447-bp PCR product. The probe hybridized with the DNA from the infected shrimp but not with the DNA from the healthy shrimp

yieiding ampiicable DNA tempiate; and (3) to est1mate approximately the proportion of the shrimp DNA and WSBV DNA in template DNA prepared from the total nucleic acids of the infected tissues. Attempts have been made in our laboratory to purify WSBV virions from various tissues including epidermis, muscle and gills. From these virions we obtained WSBV DNA of varied purity as assessed by shrimp DNA-specific primers. Examples of these assessments are shown in Figs. 3 \& 7. The nucleic acids extracted from muscle tissues yielded a great quantity of WSBV DNA, but were heavily contaminated with shrimp DNA (Fig. 6, lane 9). The virions purified from heavily infected epidermal cells underneath the exoskeleton are good starting materials for extracting 'super pure' WSBV genomic DNA (Fig. 6, lanes 2 and 5). By using the shrimp DNA-specific primers and $\mathrm{PCR}$, for the first time a tool is available to assess the extent of the shrimp DNA contamination in shrimp virus genomic DNA preparations

Using the WSBV DNA-specific primers, all the purified WSBV genomic DNA samples consistently yielded an evident amplification product showing the expected mobility of a 1447 -bp DNA fragment. The nucleic acids extracted from tissues of naturally diseased shrimp with white spot syndrome and from shrimp experimentally infected with WSBV also consistently gave PCR products of the same size. The nucleic acids extracted from the tissues of clinically healthy shrimp showed no positive results. These results demonstrate the specificity of the WSBV DNAspecific primers designed in the present study. In addition, the 1447-bp PCR product can be used to prepared WSBV-specific nucleic acid probe for detecting WSBV infection in shrimp using dot blot hybridization as shown in Fig. 9. Practically seen, the present studies provide 3 effective diagnostic tools for screening of the WSBV infection in penaeid shrimps as shown in Figs. $7,9 \& 10$.
With PCR (Fig. 7) and Southern hybridization (Fig. 10), we have demonstrated that the causative agents of white spot syndrome of different shrimp species are in fact closely related. Screening for the WSBV infection in shrimp should be undertaken immediately in order to prevent this viral disease from spreading further. In addition, the PCR diagnostic techniques for WSBV developed in the present study provide effective tools for comparative studies on shrimp non-occluded baculoviruses such as Japan' RV-PJ (Inouye et al. 1994), China' HHNBV (Cai et al. 1995), Thailand' SEMBV (Wongteerasupaya et al. 1995), Taiwan' WSBV (Wang et al. 1995) and other crustacean non-occluded baculoviruses.

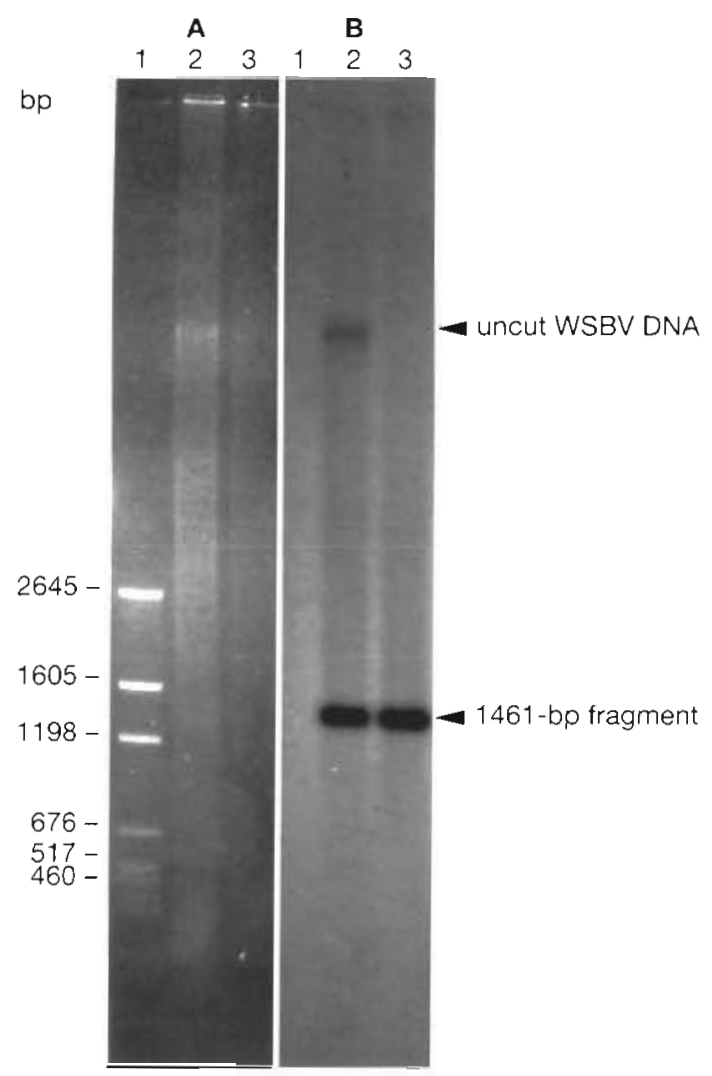

Fig. 10. Southern hybridization of WSBV DNA from diseased Penaeus monodon or P japonicus with a DIG-labeled 1447-bp PCR product. SalI-digested WSBV DNA from P. monodon and $P$. japonicus were blotted onto Hybond-N paper and probed with the DIG-labeled 1447-bp PCR product. The probe hybridized with a 1461-bp tragment of Sall digested WSBV DNA from either shrimp source with equal visual. intensity, showing their close relatedness. A: ethidium bromide-stained $0.8 \%$ agarose gel; $B$ : the autoradiograph of the Southern blot of gel A. Lane 1. pGEN DNA size marker; lane 2: genomic DNA Sall fragments of WSBV purified from P. monodon; lane 3: genomic DNA SalI fragments of WSBV purified from $P$.japonicus 
Acknowledgements. This work was supported by the Councl of Agriculture under grant No. 84-AST-1.1-FAD-62(27)B and the National Science Council under grant No. NSC 84-2321B-002-094-B04. We are indebted to Dr Jung-Yaw Lin, Institute of Binchemistry, College of Medicine, National Tarwan University for his constructive suggestions and for access to data bases. We thank Dr Mao-Sen Su and Mr Chen-Fang Chang of Tung Kang Marine Laboratory, Taiwan Fisherıes Rusearch Institute, for providing naturally infected shrimp. We also thank Dr. I Chiu Lico, Director General, Taiwan Fisheries Research Institute (TFRI), for his valuable comments.

\section{LITERATURE CITED}

Bruce LD, Trumper BB, Lightner DV (1991) Methods for vira] isolation and DNA extraction for a penaeid shrimp baculovirus. J Virol Methods 34:245-254

Chang PS, Lo CF, Kou GH, Lu CC, Chen SN (1993) Purification and amplification of DNA from Penaeus monodontype baculovirus (MBV). J Invertebr Pathol 62:116-120

Chang PS, Wang YC, Lo CF, Kou GH, Chen SN (1992) Purffcation and biochemical characteristics of occlusion body of Penaeus monodon-type baculovirus (MBV). Fish Pathol $27(3): 127-130$

Chou HY, Huang CY, Wang CH, Chiang HC, Lo CF (1995) Pathogenicity of a baculovirus infection causing white spot syndrome in cultured penaeid shrimp in Taiwan. Dis Aquat Org 23(3):165-173

Cai S, Huang J, Wang C, Song X, Sun X, Yu J, Zhang Y, Yang C (1995) Epidemiological studies on the explosive epidemic disease of prawn in 1993-1994. J Fish China 19:112-117

Couch JA (1974a) Free and occluded virus, similar to Baculovirus, in hepatopancreas of pink shrimp. Nature 247 (5438): $229-231$

Couch JA (1974b) An enzootic nuclear polyhedrosis virus of pınk shrimp: ultrastructure, prevalence and enhancement. J Invertebr Pathol 24:311-331

Erluch HH, Gelfand DH, Saiki RK (1988) Specif1C DNA amplification. Nature 331:461-462

Francki RIB, Fauquet CM, Knudson DL، Brown F (1991) Classification and nomenclature of viruses. Arch Virol (Suppl) 2:1-450

Inouye K, Miwa S, Oseko N, Nakano H, Kimura T (1994) Mass mortalities of cultured kuruma shrimp, Penaeus japonicus, in Japan in 1993: electron microscopic evidence of the causative virus. Fish Pathol 29:149-158 (in Japanese)

Johnson PT (1988) Rod-shaped nuclear viruses of crustaceans: hemocyte-infecting species. Dis Aquat Org 5: 111-122

Johnson PT, Lightner DV (1988) Rod-shaped nuclear viruses of crustaceans: gut-infecting species. Dis Aquat Org 5: $123-141$

Kim W, Abele LG (1990) Molecular phylogeny of selected decapod crustaceans based on 18s rRNA nucleotide sequences. J Crust Biol 10:1-13

Responsible Subject Editor: J. E. Stewart, Dartmouth, Nova Scotia, Canada
Lightner DV, Redman RM (1981) A baculovirus-caused disease of the penaeid shrimp. Penaeus monodon. J Invertebr Pathol 38:299-302

Lester RJG, Doubrovsky A, Paynter JL, Sambhi SK, Atherton JG (1987) Light and electron microscope evidence of baculovirus infection in the prawn Penaeus plebejus. Dis Aquat Org 3:217-219

Mari J, Bonami JR, Paulos B, Lightner DV (1993) Preliminary characterization and partial cloning of the genome of a baculovirus from Penaeus monodon (PmSNPV=MBV). Dis Aquat Org 16:207-215

Momoyama K, Hiraoka M, Nakano $H$, Koube H, Inouye $K$, Oseka N (1994) Mass mortalities of cultured kuruma shrimp, Penaeus japonicus, in Japan in 1993: histopathological study. Fish Pathol 29:141-148 (in Japanese)

Nakano H, Koube $H$, Umezaea S, Momoyama K, Hiraoka M, lnouye K, Oseko $N$ (1994) Mass mortalities of cultured kuruma shrimp, Penaeus japonicus, in Japan in 1993: epizootiological survey and infection trials. Fish Pathol 29: 135-139 (in Japanese)

Oste C (1988) Polymerase chain reaction. Biotechniques 6: 162-167

Sambrook J, Fritsch EF, Maniatis T (1989) Molecular cloning, A laboratory manual. 2nd edn. Cold Spring Harbor Laboratory Press, Cold Spring Harbor, New York

Sano T, Nishimura $T$, Oguma $K$, Momovama $K$, Takeno $N$ (1981) Baculovirus infection of cultured kuruma shrimp. Penaeus japonicus, in Japan. Fish Pathol 15:185-191

Strauss WM (1994) Preparation of genomic DNA from mammalian tissue. [n: Ausubel FM, Brent R, Kingston RE, Moore DD, Seldman JG, Smith JA, Struhl K (eds) Current protocols in molecular biology, Vol 1. Greene Publishing Associates, Inc. and John Wiley and Sons, Inc., New York, p $2.2 .1-2.2 .3$

Takahashi Y, Itamı T, Kondo M, Maeda M, Fujii R, Tomonaga S, Supamattaya K, Boonyaratpalin S (1994) Electron microscopic evidence of bacilliform virus infection in Kuruma shrimp (Penaeus japonicus). Fish Pathol 29(2):21-125

Wang CH, Lo CF, Leu JH, Chou CM, Yeh PY, Chou HY, Tung MC, Chang CF, Su MS, Kou GH (1995) Purification and genomic analysis of baculovirus associated with white spot syndrome (WSBV) of Penaeus monodon. Dis Aquat Org 23(3):239-242

Wilson K (1994) Preparation of genomic DNA from bacteria. Miniprep of bacterial genomic DNA. In: Ausubel FM, Brent R, Kingston RE, Moore DD, Seidman JG, Smith JA, Struhl K (eds) Current protocols in molecular biology, Vol 1. Greene Publishing Associates, lnc. and John Wiley and Sons, Inc., New York, p 2.4.1-2.4.5

Wongteerasupaya C, Vickers JE, Sruurairatana S, Nash GL, Akarajamorn A, Boonsaeng $V$, Panyim S, Tassanakajon A, Withyachumnarnkul B, Flegel TW (1995) A nonoccluded, systemic baculovirus that occurs in cells of ectodermal and mesodermal origin and causes high mortality in the black tiger prawn Penaeus monodon. Dis Aquat Org 21:69-77

Manuscript first received: June 23, 1995

Revised version accepted: November 12, 1995 